\title{
Teaching tourism in the Anthropocene: New technologies, fieldwork, and student involvement
}

\author{
Enseñanza del turismo en el Antropoceno: \\ Nuevas tecnologías, trabajo de campo e implicación del alumnado
}

\author{
Sandra Ricart ${ }^{1^{*}}$ (10) \\ Bas Amelung $^{2}$
}

\begin{abstract}
Humanity has affected almost every ecosystem on Earth; it has even changed how the Earth works, ushering in a new geological epoch: the Anthropocene. Climate change, biodiversity loss and the growing plastic soup in the oceans are all facets of this new epoch. Tourism is a main force behind the emergence of the Anthropocene and is also greatly impacted by it. To learn to live within the Earth's bounds requires a paradigm change that transcends the 'old ways of doing things'. Education offers our best chance of endowing new generations of professionals with the knowledge and skills to bring this paradigm change about, also in tourism. This Special Issue provides examples of methods, tools, and approaches to address environmental challenges and sustainable gaps in tourism education. The collection of articles emphasises the relevance of new technologies, fieldwork, and student involvement as building blocks for new teaching paradigms in response to the environmental challenges and tourism dynamics occurring in the Anthropocene.
\end{abstract}

Keywords: tourism; education; sustainability; Anthropocene; tools; methods; skills; experiences.

\section{Resumen}

La humanidad ha afectado a casi todos los ecosistemas terrestres, incluso ha cambiado el funcionamiento de la Tierra, marcando el comienzo de una nueva época geológica: el Antropoceno. El cambio climático, la pérdida de biodiversidad y la creciente masa de plástico en los océanos son todas facetas de esta nueva época. El turismo es un factor principal detrás del surgimiento del Antropoceno y también se ve muy afectado por él. Aprender a vivir dentro de los límites de la Tierra requiere un cambio de paradigma que trascienda las "viejas formas de hacer las cosas". La educación ofrece nuestra mejor oportunidad de dotar a las nuevas generaciones de profesionales con los conocimientos y habilidades para llevar a cabo este cambio de paradigma, también en el turismo. Este monográfico proporciona ejemplos de métodos, herramientas y enfoques para abordar los desafíos ambientales y la brecha del desarrollo sostenible en la educación turística. La colección de artículos enfatiza la relevancia de las nuevas tecnologías, el trabajo de campo y la participación de los estudiantes como bloques de construcción para nuevos paradigmas de enseñanza en respuesta a los retos ambientales y las dinámicas turísticas que ocurren en el Antropoceno.

Palabras clave: turismo; educación; sostenibilidad; Antropoceno; herramientas; métodos; habilidades; experiencias.

1 Interuniversity Institute of Geography, University of Alicante, Spain. sandra.ricart@ua.es. * Corresponding author

2 Department of Environmental Sciences, Wageningen University \& Research, The Netherlands. bas.amelung@wur.nl 


\section{Introduction}

Tourism is one of the largest economic sectors globally, representing 10.4\% of global GDP and employment, and $6.5 \%$ of global exports in 2018 (WTTC, 2019). Tourism is considered a successful tool to promote rapid economic growth (Marsiglio, 2018) and a driver of employment creation and socioeconomic development (Bianchi, 2018). However, its environmental impacts cannot be overlooked (Khan et al., 2020). The expanding tourism industry is associated with natural resource scarcity, degradation of landscapes, coastal erosion; loss of biodiversity and disruption of ecosystems; introduction of nonnative species, toxins and pollutants; wildlife habitat destruction; and an increased carbon footprint (Briassoulis, 2013; Becken, 2017). Not surprisingly, international tourism was one of the twelve key socio-economic trends, which Steffen, Sanderson \& Tyson (2004) used to illustrate the great acceleration of humanity that has been taking place since 1950. Between 1950 and 2018, the number of international tourist arrivals increased from 25 million to 1.4 billion, and this number has been projected to reach 1.8 billion in 2030 (Kongbuamai, Bui, Yousaf \& Liu, 2020). The numbers involved in domestic tourism are much bigger still. Tourism is thus a key factor in the great acceleration of humanity, which in turn is a clear indication of the emergence of humanity as a dominant force that changes and shapes the world (Moore, 2015). Humans have become a geological force in and of themselves, driving global change at an unprecedented rate (Edgeman, 2020), which led Nobel laureate Paul Crutzen to propose a new geological era: the Anthropocene, the age of mankind (Crutzen, 2002). Business-as-usual scenarios such as those developed by Gössling \& Peeters (2015) paint a dramatic picture of further expansion of tourism and its impacts in the decades ahead. The growing tension between tourism development and the environment is increasingly apparent, and also increasingly recognised by the tourism sector and tourism researchers (Brondizio et al., 2016). The concept of sustainable tourism has gained traction over the last decades; the United Nations even declared 2017 the 'International Year of Sustainable Tourism for Development'.

The concepts of sustainable development and sustainability have long been associated with the notion of the 'triple bottom line', the idea of striking a 'balance' between economic, social and environmental goals. As issues such as climate change and biodiversity loss have moved up the agenda, the finiteness of the Earth has become more centre-stage. In direct response to the emergence of the Anthropocene, a group of researchers has launched the concept of the Planetary Boundaries (Rockström et al., 2009; Steffen et al., 2015), which together delineate the safe operating space for humanity. In this conceptualisation, sustainable development is not so much a trade-off between environmental, social and economic concerns, but an imperative to remain within the Earth's carrying capacity (Torres-Valdés, Lorenzo-Álvarez, Castro-Spila \& Santa-Soriano, 2019). Raworth (2012) added social boundaries to this framework, resulting in an environmentally safe and socially fair operating space, the 'doughnut economy'. The social boundaries are strongly rooted in the United Nations Sustainable Development Goals. The tourism sector is explicitly mentioned in three of these goals, including Goal 8 (Promoting sustainable economic growth), Goal 12 (Ensuring sustainable consumption and production), and Goal 14 (Conserving and sustainably using the oceans for sustainable development). Clearly, tourism is not a tangential activity but rather a significant agent of change, modifying economies, landscapes, societies, cultures, and behaviours. It is part of the forces that affect and are affected by the geophysical changes that characterize the Anthropocene (Gren \& Huijbens, 2014, 2018; Giannetti et al., 2020).

Climate change is a case in point. It is considered the leading human and environmental crisis of the 21 st century and a clear manifestation of the Anthropocene and the need for observing Earth's carrying capacity (Hambira, Saarinen \& Moses, 2020). According to the 2008 publication from UNWTO and UN Environment entitled Climate Change and Tourism - Responding to Global Challenges, the tourism sector contributed approximately $5 \%$ of all man-made $\mathrm{CO}_{2}$ emissions, a percentage that has likely increased since then. In fact, tourism's share in emissions is bound to rise rapidly, as the aviation industry grows fast and continues to depend almost exclusively on fossil fuels, and the other sectors enter a rapid transition to a zero-emissions economy. Many countries now recognize the importance of tourism for achieving the climate change agenda: the tourism sector is quoted in 82 of the 182 Nationally Determined Contributions (NDCs) that countries submit to the United Nations Framework Convention on Climate Change (UNFCCC) to present the expected results of their planned actions regarding climate change adaptation and mitigation (Scott, Hall \& Gössling, 2019). At the same time, tourism is a highly climate-sensitive sector, as evidenced by a comprehensive review of how ten types of climate change impacts affect human health, food, water, infrastructure, economy and security (Mora et al., 2018). As it turns out, tourism was one of 
only five attributes impacted by all ten types of climate impacts. According to Ballotta, Fusai, Kyriakou, Papapostolou \& Pouliasis (2020), the entire tourism industry may crash if no urgent action is taken.

In this context of increasing attention for physical and social boundaries some tourism scholars have stated that 'sustaining tourism is not a sustainable form of tourism' (Higgins-Desbiolles, 2018) and advocated a degrowth attitude (Seraphin, Sheeran \& Pilato, 2018). Others have developed new conceptualisations such as 'overtourism' and 'tourismphobia' (Milano, Novelli \& Cheer, 2019; Oklevik et al., 2019). The United Nations World Tourism Organization (UNWTO, 2018) defines 'overtourism' as the impact of tourism on a destination or parts thereof, which excessively influences the perceived quality of life of citizens (gentrification) and/or quality of visitors' experiences in a negative way (saturation, massification) (Um $\&$ Yoon, 2020). An increasingly popular response to the challenge of overtourism emerged in southern European urban destinations, where social movements protested against the increasing pressure of tourism with slogans such as 'tourism kills the city' and 'tourists go home', which appeared in the form of stickers and graffiti (Jover \& Díaz-Parra, 2020). This call for action has been supported by critical scholarship calling for the limitation or control of tourism development to ensure place attractiveness, maintaining destination authenticity, and minimize residents' objection and social rejection (Curran et al., 2018; Jacobsen, Iversen $\&$ Hem, 2019). Others call for a limit to the number of visitors, arguing that degrowth is the only solution to revert the situation (Gascón, 2019) and return to the safe and fair operating space for humanity. 'Degrowth' calls for a radical socio-political transformation, for a planned economic contraction (Alexander, 2012) in contrast to softer proposals focused on 'decoupling', 'dematerialization' or 'green growth' (Kemp-Benedict, 2018). Pursuing degrowth globally and nationally would require a drastic transformation of the tourism industry and its metabolism (Fletcher, Murray, Blanco-Romero \& Blázquez-Salom, 2019).

Humanity, including tourism, is at a collision course with the world's environmental and social boundaries. A paradigm shift is required. As Einstein famously quipped: "We cannot solve our problems with the same thinking we used when we created them." Two decades ago, in their inaugural article launching "Tourist Studies", Franklin and Crang (2001, p. 5) stated that the study of tourism has become "stale, tired, repetitive and lifeless" because it lacks "the tools necessary to analyse and theorise the complex cultural and social processes that have unfolded". Systems thinking is a crucial element of any new paradigm. The complex problems we face today cannot be successfully addressed piece by piece and discipline by discipline, because we would continue to neglect the many important feedbacks that we have been neglecting so far. A systemic approach is needed, which integrates insights from many different fields and disciplines (e.g. geopolitics, environmental change, legislation, economic development, health, and consumer behaviour) and engages societal stakeholders (Deale, 2019). Stakeholders not only hold knowledge and values that are important to understand complex problems and develop strategies for action, they are also the ones that eventually need to implement those strategies. Tribe and Liburd (2016) signal a lack of local and tacit knowledge in tourism research and highlight a mismatch between scientific knowledge on the one side and local knowledge and stakeholder perceptions on the other. To overcome this gap, social learning is key. Student, Lamers \& Amelung (2020) therefore emphasize the usefulness of providing stakeholders with ways to 'experience and experiment with' the complex tourism system at hand. They successfully applied this hands-on approach to two coastal destinations in the Caribbean, where stakeholders grapple with the current and future impacts of climate change. Serious games proved to be effective in getting stakeholders to discuss the challenges together, better understand the feedback loops and interlinkages between them, and identify options to collaborate and address the challenges in a coordinated manner. Computer simulation proved its value in exploring the many ways in which a complex tourism system can develop and evaluate the effectiveness of intervention options.

A paradigm shift in science and society necessitates a paradigm shift in education: a shift from monodisciplinary to problem-based curricula that encompass transdisciplinary, critical and holistic approaches to sustainability (Boyle, Wilson \& Dimmock, 2015). The 'old ways of doing things' must be transcended (Dwyer, 2018). Teaching tourism in the Anthropocene requires strong guidance on conceptualisations, skills, tools and methods to guide the transformation of tourism towards sustainability (Boyle, 2015). The division of research into the dichotomy of qualitative and quantitative methods and tools is debatable and viewed by some scholars as "neither meaningful nor productive" (Shah, Shah \& Khaskhelly, 2018, p. 91). Qualitative research is appropriate to examine how social issues are generated, interpreted or experienced, but it is contextualised and is thus not generalisable (Creswell \& Creswell, 2018). Meanwhile, quantitative research involves collecting and measuring facts, observable data, and phenomena and examining causal 
relationships, but it does not explain what lies behind such relationships (Denzin \& Lincoln, 2011). Consequently, the core assumption is that the combination of qualitative and quantitative tools could provijde a more complete understanding of a research problem than either approach alone. As tourism is changing rapidly as an industry and a field of study, challenges are complicated, interconnected and involve multiple interacting systems; they thus require methodologies that can fully appreciate and critically analyse the plurality of all positions, practices and insights. Mixed methods may be such an instrument, which allows scholars to gain deep insights into complex issues (e.g. power relations) at the macro- (government), meso- (industry) and micro- (community) levels (Truong, Liu \& Yu, 2020).

Universities have an important role to play in this context (Barth and Rieckmann, 2012), not only because they generate and transfer knowledge about how to address sustainability but also because they endow future tourism professionals with the knowledge and skills needed to tackle the complex problems the industry faces (Szromek, Hysa \& Karasek, 2019). Creating room to experience and experiment with real-life complex systems is therefore as important for students as for stakeholders. Shifting the teaching paradigm is not easy (Figure 1). Educational institutions, such as universities, may be sources of innovative thinking and change, they are also strongly rooted in a society that is still dominated by the 'old way of doing things' (Hales \& Jennings, 2017). A critical first step is for instructors to no longer perceive themselves as mere content transmitters (Lillo-Bañuls, Perles-Ribes \& Fuentes, 2016), but also as coaches providing their students with opportunities to 'experience and experiment'. This requires the development of innovative pedagogical practices (Camargo \& Gretzel, 2017) and tools, aimed at teaching skills focused on lateral and systematic thinking about the sustainability of the tourism industry (Cotterell, Hales, Arcodia \& Ferreira, 2019). Examples of such innovative practices include contextualised knowledge, problem-based learning, improvisational workshops and case study analysis (Benjamin \& Kline, 2019; Dorta-Afonso, 2019).

Figure 1. Title of the figure

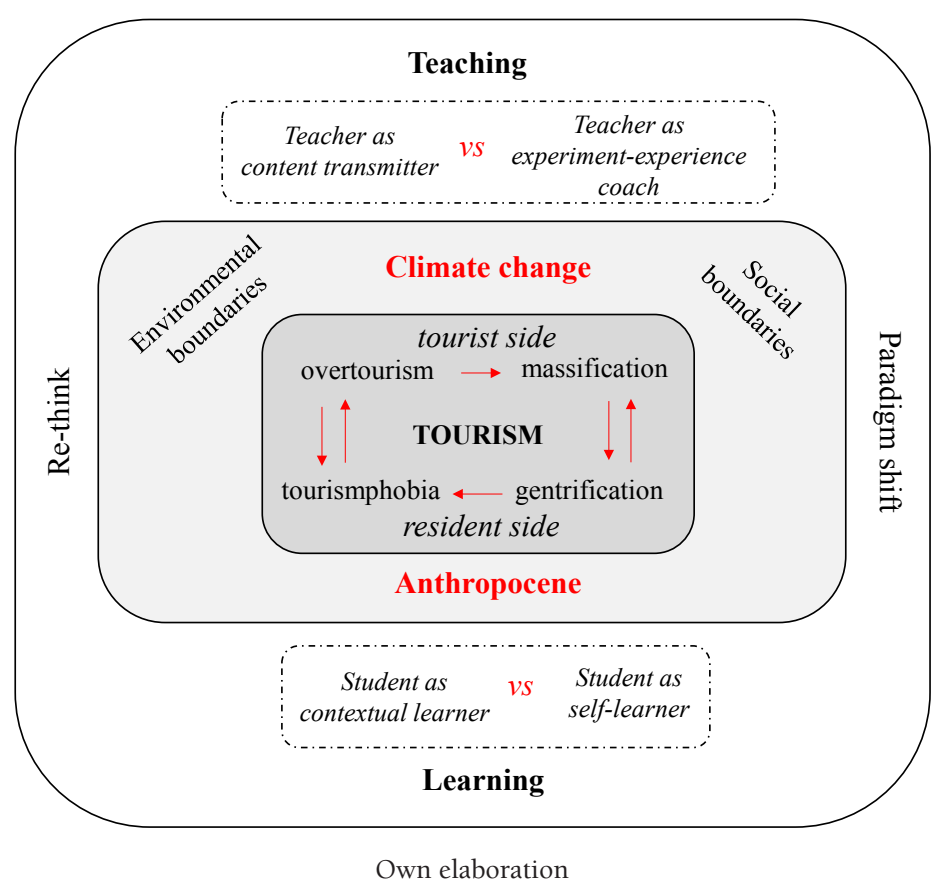

\section{Aims and scope of this Special Issue}

Educators are charged with the heavy responsibility of shaping future leaders capable of reconciling the dynamic phenomenon of tourism with the Anthropocene's environmental and social boundaries (Cotterell, Ferreira, Hales \& Arcodia, 2020). Consequently, re-tooling and re-designing tourism education is necessary to effectively address current and future challenges, emanating from the realities of the Anthropocene (Wilson, 2015). The required innovation in tourism programs can be accelerated by disseminating the best and most efficient education practices and methods with the tourism education community (Zeegers \& Clark, 2014). Tourism training must include different pedagogical approaches that train its students and promote 
skills and aptitudes while reinforcing their training in values. Consequently, training is the only way of allowing current students to become the type of professionals who will be capable of adapting to a very dynamic, fragile and extremely vulnerable sector in the future, as has been recently shown by the COVID-19 crisis, as well as looking for strategies that favour responsible consumption in the Anthropocene epoch.

Furthermore, fostering collaborations and networks is decisive. A good example is the Tourism Education Futures Initiative (TEFI), born in 2007 as a network of educators, researchers, and industry and community members seeking a progressive approach to tourism education and research. This institution recognizes sustainability as an important value to be communicated through tourism education, considering that tourism is -and will continue to be- a driving factor of social, economic and environmental change.

This Special Issue, entitled Teaching tourism in the Anthropocene, provides examples of innovative methods, tools, and approaches used in tourism programs to educate students about environmental challenges and sustainability gaps. The articles in this Special Issue discuss a number of new skills to effectively operate in the Anthropocene, but also argue for a re-appreciation of fieldwork as a way to deepen one's understanding of real-world problems with all its complexities. This Special Issue mainly targets an educational and research audience, bus since learning to live in the Anthropocene concerns us all, we hope to also inspire a broader audience in the tourism community and beyond.

\section{Exercises and experiences}

The four contributions that compose this Special Issue offer a range of perspectives, methods, and techniques and focus strongly on guidance and examples to aid teachers in effectively using new teaching methods and better using familiar ones (Table 1). 'Experience and experiment' is central to all four articles. Martínez-Hernández, Yubero, Ferreiro-Calzada \& Mendoza-de Miguel (2021) and Mínguez (2021) focus mainly on the experimentation side. They make use of Geographic Information System (GIS) techniques to explore the process of gentrification and the development of tourist routes in Madrid respectively. The authors' GIS platforms and models are not only able to replicate observed patterns, they are also potent tools in helping researchers and students to imagine and explore alternative solutions. In other words, the GIS models provide simplified representations of reality that allow students to experiment with the complex system in a laboratory-type setting. Blázquez-Salom \& Blanco-Romero (2021) and Amelung $\&$ Eijgelaar (2021), on the other hand, focus mainly on the experience side. Blázquez-Salom \& BlancoRomero (2021) advocate a re-evaluation of fieldwork as a teaching tool to help students understand the lived reality of a complex tourism problem, rather than the bloodless representation in terms of facts and figures. Experiencing a problem first-hand adds a physical and emotional layer to student's understanding of it. In their carbon footprint assignment, Amelung \& Eijgelaar (2021) make use of students' past experience, by connecting the students' latest holidays to the specific carbon footprint associated with it. This make the carbon footprint, which would otherwise be a mere number, much more relatable and tangible. It acquires even more meaning when students compare their own holiday's carbon footprint to that of others' and to their own annual carbon footprint. Similar to the fieldwork proposed by Blázquez-Salom \& Blanco-Romero (2021), the carbon footprint assignment results in a more profound understanding of the complex problem at hand, by adding emotions to cognition.

Table 1. Experience and experiment sides of the contributions

\begin{tabular}{|c|c|c|c|}
\hline Side & Contribution & Innovative pedagogical benefit & Tool \\
\hline \multirow[t]{2}{*}{ Experimentation } & $\begin{array}{l}\text { Martínez-Hernández, Yubero, } \\
\text { Ferreiro-Calzada \& Mendoza-de } \\
\text { Miguel (2021) }\end{array}$ & $\begin{array}{l}\text { Contemporary dynamics } \\
\text { Causes and consequences of a } \\
\text { phenomena }\end{array}$ & \multirow{2}{*}{$\begin{array}{l}\text { Geographic Information } \\
\text { Systems (GIS) }\end{array}$} \\
\hline & Mínguez (2021) & $\begin{array}{l}\text { Collaboration and co-evaluation } \\
\text { Digital competences }\end{array}$ & \\
\hline \multirow{2}{*}{ Experience } & $\begin{array}{l}\text { Blázquez-Salom \& Blanco-Romero } \\
\text { (2021) }\end{array}$ & $\begin{array}{l}\text { The lived reality } \\
\text { Protocol for teaching }\end{array}$ & Fieldwork \\
\hline & Amelung \& Eijgelaar (2021) & $\begin{array}{l}\text { Students' past experience } \\
\text { Challenges and potential solutions }\end{array}$ & Carbon Footprint Assessment \\
\hline
\end{tabular}

Own elaboration 


\subsection{The experimentation sides}

Martínez-Hernández, Yubero, Ferreiro-Calzada \& Mendoza-de Miguel (2021) present an innovative teaching activity to facilitate the understanding of contemporary dynamics of commercial transformation in contexts of tourism gentrification. In their article "Didactic use of GIS and street view for tourism degree students: understanding commercial gentrification in large urban destinations", they approach tourism gentrification as a complex phenomenon in large urban destinations and an important topic for future tourism professionals, who must be aware of its characteristics and understand its causes and consequences. To help understand the causes and consequences of tourism gentrification, the authors follow a digital cartography making strategy. Using Google Street View, the retail businesses in several streets of Madrid were identified and georeferenced at very points in time, past and present. Geographic Information Systems (GIS) are subsequently used to visualise commercial transformations of each selected street, through a so-called cartographic comparator application. The transfer from the universities of updated knowledge and critical interpretative frameworks of social reality is a challenge, so the activity presented in this paper follows a Sustainable Tourism Pedagogy approach that advocates for sustainable tourism education in continuous co-creation whole society. To ensure replicability in other touristified cities, a 4-phase methodological design was proposed. The didactic activity is (i) customisable as there is an initial investigation of previous ideas, curricular founded, of each specific group of students, as well as the selection of the study streets is adaptable regarding specific criteria; (ii) realisable, as knowledge of the topic is significant and adequate in extension, data, clarity and task sequencing; (iii) collaborative, as students undertake a collective idea-sharing task that responds to a didactically based script, thus providing a basis for sharing the work of each group of students and channelling it towards academic reflection; and (iv) evaluable, as a didactic evaluation questionnaire allows to evaluate its effectiveness and, if necessary, improve the activity for future replications. The contribution of Martínez-Hernández et al. (2021) reveals a knowledge structure focused on the role of residents, commercial transformation, touristification, the gentrification process, and the use of GIS as an analytical tool. This last point (the use of GIS) can serve to encourage teachers using Information and Communication Technologies (ICT), not only to facilitate the learning of complex territorial phenomena but also to acquire the ability to use new digital tools that are highly valued in the tourism sector.

Mínguez (2021)'s contribution, entitled "Teaching tourism: urban routes design using GIS Story Map", focuses on the power of GIS applications to endow tourism degree students with essential competencies. The article describes how students use a collaborative work methodology and geospatial technologies (especially the GIS Story Map) to create a tourist product based on a virtual itinerary for tourists. With Madrid as a case study area, students are asked to design tourist routes, taking them through all phases of the development process, from planning to development, promotion and evaluation. Via strategies such as self-learning and co-evaluation, students acquire skills such as creativity, teamwork, planning and organising, as well as narrative, spatial and digital competencies. This teaching method is not easy and requires significant preparation by the teacher and constant monitoring, but the results from the Madrid case study are positive, and the potential applications are virtually limitless, in tourism and beyond. The study of Mínguez (2021) reveals a knowledge structure focused on the role of the teamwork, the need for information (image, map) about a city, and the use of GIS to provide a final product. Interestingly, the provision of a virtual product for tourists is especially striking at the specific time when the work has been carried out, characterised by the confinement caused by the COVID-19 quarantine and an intense debate on the immediate future of tourism considering natural and social limits.

\subsection{The experience sides}

Blázquez-Salom \& Blanco-Romero's (2021) contribution highlights the usefulness of fieldwork and the analysis of local phenomena to deepen on the Geography of tourism. The article entitled "Fieldworking in Ground Zero, Mallorca. Methodological proposal fieldwork for geographical analysis of tourist areas" draws a parallel between fieldwork and laboratory research. It provides a detailed protocol for teaching and research techniques regarding fieldwork, contributing as no other to contrast the geographic knowledge with reality. Geographical fieldwork is a connective practice that allows creating an empathic and emotional relationship between the learner and an "other", alleviating alienation from reality. Fieldwork combines the direct collection of data and the development of more comprehensive exploratory and explanatory methods for geographic analysis. The authors provide a specific procedure of an educational process for 
field working in Geography, consisting of eight steps (from a conceptual framework to an evaluation among equals). They apply it to the Spanish island of Mallorca, where inhabitants have protested against the negative impacts of mass tourism, demanding a stop to the growth of urban tourism. This application confirms that the approach helps students acquire a number of essential competencies: a) autonomy in the task of analysing reality to facilitate the acquisition of significant knowledge; b) attachment to the environment, to internalise humanity's responsibilities regarding global change in the Anthropocene; c) ability to search for solutions to the socio-ecological problems at hand.

The last contribution, presented by Amelung \& Eijgelaar (2021) and entitled "The holiday carbon footprint in tourism education: Learning from practice and experience" reports on ten years of teaching experience with a carbon footprint exercise. Students of a BSc tourism programme calculate the carbon footprint of their latest holiday, compare their results with others and reflect on options to reduce emissions. The carbon footprint has been accepted as a legitimate indicator for calculating environmental impacts by a continuously increasing group of stakeholders, both inside and outside the tourism industry. This assignment has a threefold objective: 1) to allow students to practice with carbon footprint calculations; 2) to provide students with a very personalized context to help them interpret information about emissions statistics, and 3) to help students get a better feel for the relative importance of a variety of factors determining tourism emissions. Furthermore, the exercise combines individual and collaborative work and directly connects to students' personal experience. In a very natural and compelling way, it leads students to conclude that distance, transport mode, length of stay and levels of luxury are the key determinants of holiday emissions. Besides its effectiveness in reaching the learning outcomes, the exercise has major practical strengths: 1) it is low-key and accessible (the exercise does not require any prior knowledge), 2) it is highly scalable (it works with 10 students, but also with 100 students or more), and 3) it is fun (students are eager to learn about the carbon footprint of their holidays while promoting social process when comparing their results with those of others). Furthermore, the knowledge structure of this experience was focused on relating students' personal holiday experience with the industry's great mitigation challenges, fostering reflection on nature of those challenges and potential solutions. By comparing their respective carbon footprints, students engage in a social-learning process.

\section{Future challenges}

We live in the Anthropocene, the geological epoch shaped by mankind. The challenges of our time, including global environmental change, globalisation and pandemics, call for fundamental changes to the curricula in tourism education to equip students with the knowledge, tools and attitude needed to address those challenges. Systemic, rather than mono-disciplinary approaches should be encouraged. Furthermore, tourism education has much to gain active and participatory learning processes because it encourages learners to ask critical reflective questions, clarify values, envision more positive futures, think systemically, respond through applied learning, and explore dialectics (Bowan \& Dallam, 2020; MacKenzie \& Gannon, 2019). The contributions included in this Special Issue promote critical thinking by combining individual and collaborative experiences, which fits well with one of the main goals of the Strategic Framework for Education and Training 2020: enhancing creativity and innovation at all levels of education and training (Liu, Horng, Chou \& Huang, 2017). Tourism programs must equip their students with theoretical and practical sustainability knowledge based on individual competencies and team empowerment, working in real-life projects that can increase students' contribution to a more sustainable world (Jennings, Kensbock \& Kachel, 2010). However, truly transformative practices in higher education are unfortunately not the norm due to the obsession for ranking-tables, metrics, and other efficiency measurements where students are regarded as input and output in a system, rather than individuals who have the potential to transform the realities we all inhabit (Edelheim, 2020). To address this gap, the contributions collected in this Special Issue highlight how field of tourism studies is particularly well suited to techniques and methods that expose students to the complexity of tourism issues (McGrath et al., 2021). Emanating from all four articles is the need to go beyond knowledge transfer and provide students with platforms to experience and experiment with complex tourism systems. Being part of the experience by applying different tools and methods, students and teachers can reduce the distance between what is already known about tourism and what remains to be known in the near future according to Anthropocene challenges. 
This Special Issue covers subjects (e.g., gentrification, mass tourism, carbon footprint) that are often found split between environmental and social approaches, without deepening in how teaching tourism could help achieve environmental change through a specific set of knowledge elements, skills, tools, methods, and approaches focused on students' participation (Mau \& Harkness, 2020). These contributions based on more systemic and integrated approaches are mandatory in the Anthropocene era as a framework for improving tourism educational programs in line with environmental and climate change challenges. Considering the authors' background, this Special Issue is primarily addressed to the educational and research community as it provides knowledge about the value of applying new educational activities in which new technologies, fieldwork, and student's involvement should be promoted. Furthermore, this Special Issue should be useful for tourism managers and decision-makers as a first step towards customizing their interventions at local and regional scales. Tourism curricula will be revised, and students and researchers will achieve an enhanced understanding of sustainability issues from practice. We hope to have contributed to reaching this aim somehow with the articles gathered in the following pages.

\section{Acknowledgments}

The Guest Editors of this Special Issue want to thank all the authors for sharing their knowledge and experience, and the reviewers for their valuable suggestions. We appreciate the trust that the Investigaciones Geográficas journal has given us to carry out this nice venture. Finally, we would like to thank Prof. Antonio M. Rico-Amorós and Jorge Olcina-Cantos (Co-Editors-in-Chief) and Clotilde Esclapez (Managing Editor) for their kind support and invaluable guidance during the entire production and editing process.

\section{References}

Alexander, S. (2012). Planned economic contraction: The emerging case for degrowth. Environmental Politics, 21(3), 349-368. http://dx.doi.org/10.1080/09644016.2012.671569

Amelung, B. \& Eijgelaar, E. (2021). The holiday carbon footprint in tourism education: Learning from practice and experience. Investigaciones Geogräficas, (75), 87-97. https://doi.org/10.14198/INGEO2020.AE

Ballotta, L., Fusai, G., Kyriakou, I., Papapostolou, N.C. \& Pouliasis, P.K. (2020). Risk management of climate impact for tourism operators: An empirical analysis of ski resorts. Tourism Management, 77, 104011. http://dx.doi.org/10.1016/j.tourman.2019.104011

Barth, M. \& Rieckmann, M. (2012). Academic staff development as a catalyst for curriculum change towards education for sustainable development: an output perspective. Journal of Cleaner Production, 26, 28-36. http://dx.doi.org/10.1016/j.jclepro.2011.12.011

Becken, S. (2017). Evidence of a low-carbon tourism paradigm? Journal of Sustainable Tourism, 25(6), 832-850. http://dx.doi.org/10.1080/09669582.2016.1251446

Benjamin, S. \& Kline, C. (2019). How to yes-and: Using improvisational games to improve communication, listening, and collaboration techniques in tourism and hospitality education. Journal of Hospitality, Leisure, Sports and Tourism Education, 24, 130-142. http://dx.doi.org/10.1016/j.jhlste.2019.02.002

Bianchi, R. (2018). The political economy of tourism development: A critical review. Annals of Tourism Research, 70, 88-102. http://dx.doi.org/10.1016/j.annals.2017.08.005

Blázquez-Salom, M. \& Blanco-Romero, A. (2021). Fieldwork in ground zero, Mallorca. A methodological fieldwork proposal for a geographical analysis of tourist areas. Investigaciones Geográficas, (75), 43-59. https://doi.org/10.14198/INGEO2020.BB

Bowan, D. \& Dallam, G. (2020). Building bridges: overview of an international sustainable tourism education model. Journal of Teaching in Travel \& Tourism, 20(3), 202-215. http://dx.doi.org/10.1080/ $\underline{15313220.2020 .1797609}$

Boyle, A.R. (2015). Space for sustainability? From curriculum to critical thinking in Australian tourism higher education (Doctoral dissertation, unpublished). Lismore (Australia).

Boyle, A., Wilson, E. \& Dimmock, K. (2015). Transformative education and sustainable tourism: The influence of a lecturer's worldview. Journal of Teaching in Travel \& Tourism, 15(3), 252-263. http:// dx.doi.org/10.1080/15313220.2015.1059303 
Briassoulis, H. (2013). Environmental impacts of tourism: A framework for analysis and evaluation. In H. Briassoulis \& J. Van der Straaten (Eds.), Tourism and the environment: Regional, economic, cultural and policy (vol. 6). New York: Springer Science \& Business Media.

Brondizio, E., O’Brien, K., Bai, X., Biermann, F., Steffen, W., Berkhout, F., ... \& Chen, C.-T.A. (2016). Reconceptualizing the Anthropocene: A call for collaboration. Global Environmental Change, 39, 318327. http://dx.doi.org/10.1016/j.gloenvcha.2016.02.006

Camargo, B.A. \& Gretzel, U. (2017). What do tourism students know about sustainability and sustainable tourism? An exploratory study of Latin American students. Journal of Teaching in Travel E Tourism, 17(2), 101-117. http://dx.doi.org/10.1080/15313220.2017.1294038

Cotterell, D., Hales, R., Arcodia, C. \& Ferreira, J.-A. (2019). Overcommitted to tourism and under committed to sustainability: the urgency of teaching "strong sustainability" in tourism courses. Journal of Sustainable Tourism, 27(7), 882-902. http://dx.doi.org/10.1080/09669582.2018.1545777

Cotterell, D., Ferreira, J.-A., Hales, R. \& Arcodia, C. (2020). Cultivating conscientious tourism caretakers: a phenomenographic continuum towards stronger sustainability. Current Issues in Tourism, 23(8), 1004-1020. http://dx.doi.org/10.1080/13683500.2019.1577369

Creswell, J.W. \& Creswell, D.J. (2018). Research design: Qualitative, quantitative, and mixed methods approaches. Washington, DC: Sage.

Crutzen, P.J. (2002). Geology of mankind. Nature 415, 23. http://dx.doi.org/10.1038/415023a

Curran, R., Baxter, I.W.F., Collinson, E., Gannon, M.J., Lochrie, S., Taheri, B., ... \& Yalinay, O. (2018). The traditional marketplace: serious leisure and recommending authentic travel. The Service Industries Journal, 38(15-16), 1116-1132. http://dx.doi.org/10.1080/02642069.2018.1432603

Deale, C.S. (2019). Making memories: An example of the scholarship of teaching and learning in Hospitality and Tourism Education. Journal of Hospitality \& Tourism Education, 31(4), 221-234. http:// dx.doi.org/10.1080/10963758.2019.1575749

Denzin, N.K. \& Lincoln, Y.S. (Eds) (2011). The Sage handbook of qualitative research. Thousand Oaks, CA: Sage.

Dorta-Afonso, D. (2019). Teaching organizational behaviour in the bachelor of tourism through the case study method. Journal of Hospitality, Leisure, Sport E Tourism Education, 25, 100204. http://dx.doi. org/10.1016/j.jhlste.2019.100204

Dwyer, L. (2018). Saluting while the ship sinks: the necessity for tourism paradigm change. Journal of Sustainable Tourism, 26(1), 29-48. http://dx.doi.org/10.1080/09669582.2017.1308372

Edelheim, J. (2020). How should tourism education values be transformed after 2020? Tourism Geographies, 22(3), 547-554. http://dx.doi.org/10.1080/14616688.2020.1760927

Edgeman, R. (2020). Urgent evolution: excellence and wicked Anthropocene Age challenges. Total Quality Management, 31(5), 469-482. http://dx.doi.org/10.1080/14783363.2018.1430510

Fletcher, R., Murray, I., Blanco-Romero, A. \& Blázquez-Salom, M. (2019). Tourism and degrowth: an emerging agenda for research and praxis. Journal of Sustainable Tourism, 27(12), 1745-1763. http:// dx.doi.org/10.1080/09669582.2019.1679822

Franklin, A. \& Crang, M. (2001). The trouble with tourism and travel theory?. Tourist Studies, 1(1), 5-22. http://dx.doi.org/10.1177/146879760100100101

Gascón, J. (2019). Tourism as a right: a "frivolous claim" against degrowth? Journal of Sustainable Tourism, 27(12), 1825-1838. http://dx.doi.org/10.1080/09669582.2019.1666858

Giannetti, B.F., Agostinho, F., Almeida, C.M.V.B., Liu, G., Contreras, L.E.V., Vandecasteele, C., ... \& Poveda, C. (2020). Insight on the United Nations Sustainable Development Goals scope: Are they aligned with a 'strong' sustainable development? Journal of Cleaner Production, 252, 119574. http:// dx.doi.org/10.1016/j.jclepro.2019.119574

Gössling, S. \& Peeters, P. (2015). Assessing tourism's global environmental impact 1900-2050. Journal of Sustainable Tourism, 23(5), 639-659. http://dx.doi.org/10.1080/09669582.2015.1008500

Gren, M. \& Huijbens, E.H. (2014). Tourism and the Anthropocene. Scandinavian Journal of Hospitality and Tourism, 14(1), 6-22. http://dx.doi.org/10.1080/15022250.2014.886100 
Gren, M., \& Huijbens, E.H. (Eds.) (2018). Tourism and the Anthropocene. London: Routledge.

Hales, R. \& Jennings, G. (2017). Transformation for sustainability: The role of complexity in tourism students' understanding of sustainable tourism. Journal of Hospitality, Leisure, Sport \& Tourism Education, 21, 185-194. http://dx.doi.org/10.1016/j.jhlste.2017.08.001

Hambira, W.L., Saarinen, J. \& Moses, O. (2020). Climate change policy in a world of uncertainty: changing environment, knowledge, and tourism in Botswana. African Geographical Review, 39(3), 252-266. http://dx.doi.org/10.1080/19376812.2020.1719366

Higgins-Desbiolles, F. (2018). Sustainable tourism: Sustaining tourism or something more? Tourism Management Perspectives, 25, 157-160. http://dx.doi.org/10.1016/j.tmp.2017.11.017

Jacobsen, J.K.D., Iversen, N.M. \& Hem, L.H. (2019). Hotspot crowding and over-tourism: Antecedents of destination attractiveness. Annals of Tourism Research, 76, 53-66. http://dx.doi.org/10.1016/j. annals.2019.02.011

Jennings, G., Kensbock, S. \& Kachel, U. (2010). Enhancing "Education about and for sustainability" in a tourism studies enterprise management course: An action research approach. Journal of Teaching in Travel \& Tourism, 10(2), 163-191. http://dx.doi.org/10.1080/15313221003792019

Jover, J. \& Díaz-Parra, I. (2020). Who is the city for? Overtourism, lifestyle migration and social sustainability. Tourism Geographies, Latest Articles. http://dx.doi.org/10.1080/14616688.2020.1713878

Kemp-Benedict, E. (2018). Dematerialization, decoupling, and productivity change. Ecological Economics, 150, 204-216. http://dx.doi.org/10.1016/j.ecolecon.2018.04.020

Khan, A., Bibi, S., Ardito, L., Lyu, J., Hayat, H. \& Arif, A.M. (2020). Revisiting the dynamics of tourism, economic growth, and environmental pollutants in the emerging countries - Sustainable tourism policy implication. Sustainability, 12, 2533. http://dx.doi.org/10.3390/su12062533

Kongbuamai, N., Bui, Q., Yousaf, H.M.A.U. \& Liu, Y. (2020). The impact of tourism and natural resources on the ecological footprint: a case study of ASEAN countries. Environmental Science and Pollution Research, 27, 19251-19264. http://dx.doi.org/10.1007/s11356-020-08582-x

Lillo-Bañuls, A., Perles-Ribes, J.F. \& Fuentes, R. (2016). Wiki and blog as teaching tools in tourism higher education. Journal of Teaching in Travel \& Tourism, 16(2), 81-100. http://dx.doi.org/10.1080/153132 $\underline{20.2015 .1118367}$

Liu, C-H., Horng, J.S., Chou, S.F. \& Huang, Y-C. (2017). Analysis of tourism and hospitality sustainability education with co-competition creativity course planning. Journal of Hospitality, Leisure, Sport \& Tourism Education, 21(Part A), 88-100. https://doi.org/10.1016/j.jhlste.2017.08.008

MacKenzie, N. \& Gannon, M.J. (2019). Exploring the antecedents of sustainable tourism development. International Journal of Contemporary Hospitality Management, 31(6), 2411-2427. http://dx.doi. org/10.1108/IJCHM-05-2018-0384

McGrath, G.M., Lockstone-Binney, L., Ong, F., Wilson-Evered, E., Blaer, M. \& Whitelaw, P. (2021). Teaching sustainability in tourism education: a teaching simulation. Journal of Sustainable Tourism, 29(5), 795-812. http://dx.doi.org/10.1080/09669582.2020.1791892

Marsiglio, S. (2018). On the implications of tourism specialization and structural change in tourism destinations. Tourism Economics, 24(8), 945-963. https://doi.org/10.1177/1354816618784788

Martínez-Hernández, C., Yubero, C., Ferreiro-Calzada E. \& Mendoza-de Miguel, S. (2021). Didactic use of GIS and Street View for Tourism Degree students: understanding commercial gentrification in large urban destinations. Investigaciones Geográficas, (75), 61-85. https://doi.org/10.14198/INGEO2020.MYFM

Mau, S.T. \& Harkness, S.S. (2020). The role of teacher educators and university supervisors to help student teachers reflect: from monological reflection toward dialogical conversation. Reflective Practice, 21(2), 171-182. http://dx.doi.org/10.1080/14623943.2020.1716710

Milano, C., Novelli, M. \& Cheer, J.M. (2019). Overtourism and Tourismphobia: A journey through four decades of tourism development, planning and local concerns. Tourism Planning \& Development, 16(4), 353-357.

Mínguez, C. (2021). Teaching tourism: urban routes design using GIS Story Map. Investigaciones Geográficas, (75), 25-42. https://doi.org/10.14198/INGEO2020.M 
Moore, A. (2015). Tourism in the Anthropocene park? New analytic possibilities. International Journal of Tourism Anthropology, 4(2), 186-200. http://dx.doi.org/10.1504/IJTA.2015.070067

Mora, C., Spirandelli, D., Franklin, E.C., Lynham, J., Kantar, M.B., Miles, W., ... \& Hunter, C.L. (2018). Broad threat to humanity from cumulative climate hazards intensified by greenhouse gas emissions. Nature Climate Change, 8(12), 1062-1071. http://dx.doi.org/10.1038/s41558-018-0315-6

Oklevik, O., Gössling, S., Hall, C.M., Jacobsen, J.K.S., Grøtte, I.P. \& McCabe, S. (2019). Overtourism, optimisation, and destination performance indicators: a case study of activities in Fjord Norway. Journal of Sustainable Tourism, 27(12), 1804-1824. http://dx.doi.org/10.1080/09669582.2018.1533020

Raworth, K. (2012). A safe and just space for Humanity: Can we live within the doughnut? Oxfam Discussion Papers. Retrieved from https://www-cdn.oxfam.org/s3fs-public/file attachments/dp-asafe-and-just-space-for-humanity-130212-en_5.pdf

Rockström, J., Steffen, W., Noone, K., Persson, A., Chapin, F.S., Lambin, E.F., ... \& Foley, J.A. (2009). A safe operating space for humanity. Nature, 461, 472-475. http://dx.doi.org/10.1038/461472a

Scott, D., Hall, C.M. \& Gössling, S. (2019). Global tourism vulnerability to climate change. Annals of Tourism Research, 77, 49-61. http://dx.doi.org/10.1016/j.annals.2019.05.007

Seraphin, H., Sheeran, P. \& Pilato, M. (2018). Over-tourism and the fall of Venice as a destination. Journal of Destination Marketing \& Management, 9, 374-376. http://dx.doi.org/10.1016/j.jdmm.2018.01.011

Shah, S.S., Shah, A.A. \& Khaskhelly, N. (2018). Pragmatism research paradigm: a philosophical framework of advocating methodological pluralism in social science research. Grassroots, 52, 90-101.

Steffen, W., Sanderson, A. \& Tyson, P.D. (2004) Global change and the Earth System: A planet under pressure. The IGBP Book Series. Berlin, Heidelberg, New York: Springer-Verlag.

Steffen, W., Richardson, K., Rockström, J., Cornell, S.E., Fetzer, I., Bennett, E.M., ... \& Sörlin, S. (2015). Planetary boundaries: Guiding human development on a changing planet. Science, 347(6223), 1259855. http://dx.doi.org/10.1126/science.1259855

Student, J., Lamers, M. \& Amelung, B. (2020). A dynamic vulnerability approach for tourism destination. Journal of Sustainable Tourism, 28(3), 475-496. http://dx.doi.org/10.1080/09669582.2019.1682593

Szromek, A.R., Hysa, B. \& Karasek, A. (2019). The perception of overtourism from the perspective of different generations. Sustainability, 11, 7151. http://dx.doi.org/10.3390/su11247151

Torres-Valdés, R., Lorenzo-Álvarez, C., Castro-Spila, J. \& Santa-Soriano, A. (2019). Relational university, learning and entrepreneurship ecosystems for sustainable tourism. Journal of Science and Technology Policy Management, 10(4), 905-926. http://dx.doi.org/10.1108/JSTPM-03-2018-0032

Tribe, J. \& Liburd, J.J. (2016). The tourism knowledge system. Annals of Tourism Research, 57, 44-61. http://dx.doi.org/10.1016/j.annals.2015.11.011

Truong, D., Liu, R.X. \& Yu, J. (2020). Mixed methods research in tourism and hospitality journals. International Journal of Contemporary Hospitality Management, 32(4), 1563-1579. http://dx.doi. org/10.1108/IJCHM-03-2019-0286

Um, J. \& Yoon, S. (2020). Evaluating the relationship between perceived value regarding tourism gentrification experience, attitude, and responsible tourism intention. Journal of Tourism and Cultural Change, Latest Articles. http://dx.doi.org/10.1080/14766825.2019.1707217

United Nations World Tourism Organization (UNWTO) (2018). International tourism highlights 2019 edition. Madrid: UNWTO. http://dx.doi.org/10.18111/9789284421152

Wilson, E. (2015). Practice what you teach: Teaching sustainable tourism through a critically reflexive approach. In G. Moscardo \& P. Benckendorff (Eds.), Education for sustainability in tourism (pp. 201-211). New York: Springer.

World Travel \& Tourism Council (WTTC) (2019). You've reached your destination. Best practices enabling the growth of travel \& tourism. World Travel \& Tourism Council. Retrieved from https:// wttc.org/en-gb/Initiatives/Sustainable-Growth/moduleId/1191/itemId/59/

Zeegers, Y. \& Clark, I. (2014). Students' perceptions of education for sustainable development. International Journal of Sustainability in Higher Education, 15(2), 242-253. 